\title{
THE EFFECTIVE ROLE OF SELENIUM AND ZINC ON BROILERS PERFORMANCE
}

\author{
Fayza M. Salem ${ }^{1}$, Amal M. Hassan ${ }^{2}$, A.A. Abd El-Dayem ${ }^{1}$ and K. Abd El-Galil ${ }^{1}$ \\ ${ }^{1}$ Animal and Poultry Nutrition Department, Desert Research Center, Cairo, Egypt. \\ ${ }^{2}$ Animal and Poultry Physiology Department, Desert Research Center, Cairo, Egypt.
}

(Received 7/1/2019, accepted 25/2/2019)

\section{SUMMARY}

$\mathrm{N}$ inety unsexed one day old Cobb 500 broiler chicks were used in this experiment. The experiment aimed to study the comparative effect of some feed additives as growth promoters such as selenium and zinc in their inorganic form on broiler growth rate, feed intake, feed efficiency, some blood metabolites and carcass traits by adding them in the drinking water. The chicks were randomly distributed into three equal treatments. Each treatment had 30 chicks divided equally into five replicates. The experimental treatments were: The first treatment was served as a control (T1), while the second (T2) was given $0.8 \mathrm{mg}$ sodium selenite / $\mathrm{L}$ of drinking water and the third treatment (T3) was given $1 \mathrm{~g}$ zinc oxide/ L. Sodium selenite (T2) showed the heaviest body weight $(\mathrm{P}<0.01)$, gained more weight consumed more feed and recorded the best value of feed efficiency ratio $(\mathrm{P}<0.001)$ compared to the other treatments. There were non-significant differences between control and zinc treatments in body weight and gain and feed efficiency ratio. There was a significant reduction in feed intake from 21 to 35 days of age and from 1 to 35 days of age for zinc treatment compared to the other treatments and significant increase from 1 to 21 days of age for the same treatment. A significant increase in triiodothyronine $\left(\mathrm{T}_{3}\right)(\mathrm{P}<0.01)$ was observed in selenium and zinc treatments $(\mathrm{T} 2$ and $\mathrm{T} 3$ respectively) compared to the control treatment. About plasma urea, creatinine, ALT and AST, total lipid, cholesterol, triglycerides, total protein, albumin, globulin and their ratio (A/G ratio) and carcass traits, there were nonsignificant $(\mathrm{P}>0.05)$ differences among the experimental treatments. Zinc treatment $(\mathrm{T} 3)$ recorded the lowest percent $(3.85 \%)$ of mortality. It was concluded that supplementation of selenium in broiler drinking water improved broiler performance and zinc addition did not have adverse effects on growth rate and the functions of blood.

Keywords: Broiler, selenium, zinc, and drinking water.

\section{INTRODUCTION}

There is growing concern about the way to increase the effectiveness and the bioavailability of trace minerals such as selenium and zinc in their inorganic form on the growth and productive performance of broiler. On the other hand, the recommended doses of trace minerals used in broiler nutrition are taken from the National Research Council documents (NRC, 1994) which are based on the results of old researches. So that, the amounts of trace elements which always add in poultry diets to completely meet their needs are not exactly known. Huang et al. (2007) recommended that $\mathrm{Zn}$ requirement for the broilers from hatch to $21 \mathrm{~d}$ of age is $84 \mathrm{mg} / \mathrm{kg}$ diet, twice the recommended value (40 mg/kg diet) of NRC (1994) to meet all the metabolic needs. Therefore, the Ross 308 (2009) management guide established broiler zinc requirements during the grower period is $120 \mathrm{mg} \mathrm{Zn/kg} \mathrm{diet.} \mathrm{Selenium} \mathrm{and} \mathrm{zinc} \mathrm{requirements} \mathrm{for} \mathrm{broilers} \mathrm{are} 0.15$ and $40 \mathrm{mg} / \mathrm{kg} \mathrm{diet}$ respectively according to NRC (1994). The absorption of minerals and their bioavailability is affected by the form which are ingested and principles of biochemistry show that minerals in a liquid medium can be expected to be more absorbed and efficient due to their smaller size and larger surface area and the solubility of a mineral has been shown to enhance its bioavailability (Schlussel, 2006), so that, minerals in solid forms must be dissolute prior to being available for absorption by poultry. Selenium and zinc are types of trace elements that have a vital role in various metabolic reactions that resulted in better growth rate and feed efficiency. Selenium is required as a component of antioxidant enzymes such as glutathione peroxidase which destroy free radicals produced during the metabolic activity (Rotruck et al., 1973). It also acts as an 


\section{Salem et al.}

immuno-stimulating substance to increase the ability of the immune system to resist diseases. Therefore, selenium is important for digestive enzymes secretion and thereby improving nutrient digestibility and performance (Macpherson, 1994; Combs and Combs, 1986). Zinc has a catalytic role in over 200-300 enzymes, it increases the synthesis of metallo-thionein, a cystine-rich protein that acts as a free radical scavenger (Oteiza et al., 1996) so that, It acts as antioxidant substance. Zinc also has an important role in the immune system.

Based on these researches, the objective of this study is to compare the effectiveness of inorganic selenium and zinc on improving the performance of broiler by adding them in drinking water.

\section{MATERIALS AND METHODS}

The present study was carried out at South Sinai Experimental Research Station (Ras-Suder City) which belongs to the Desert Research Center. The experiment aimed to study the comparative effect of some feed additives as growth promoters such as selenium and zinc in their inorganic form on broiler growth rate, feed intake, feed efficiency, some blood metabolites and carcass traits by adding them in the drinking water.

The selected source of selenium was a solution contains $80 \mathrm{mg}$ sodium selenite $\left(\mathrm{Na}_{2}-\mathrm{SeO}_{3}\right)$ and $5.486 \mathrm{gm}$ vitamin E (Alpha - tocopherol acetate). The dosage used was $10 \mathrm{ml}$ from the solution / liter of drinking water which provides $0.8 \mathrm{mg}$ sodium selenite / liter of drinking water. About zinc oxide, the dose was $1 \mathrm{~g}$ powder / liter of water. Selenium and zinc were added per liter of drinking water with every new addition of water.

Ninety unsexed one day old Cobb 500 chicks purchased from a commercial hatchery and were randomly distributed into three treatments with five replicates per each treatment (six chicks for per replicate). All chicks were vaccinated. Light was constant for 24 hours daily throughout the first experimental week then 23 hours after that week. . Feed and water were offered ad libitum. Chick's body weight and feed intake were weekly recorded and feed efficiency ratio (g feed/g gain) was calculated per each pen. The mortality rate was recorded during the whole period of the experiment. The experimental birds were housed in ventilated open house into vertical batteries ( $160 \mathrm{~cm}$ length $\mathrm{x} 200$ height $\mathrm{x} 160$ width) contain three rows in each side, each row contains two cages (100 cm length x 40 height).

Three experimental diets were used and formulated based on the NRC (1994) for starter, grower and finisher periods (Table 1). The experimental treatments were control (T1), $0.8 \mathrm{mg}$ sodium selenite / liter of drinking water (T2) and $1 \mathrm{~g}$ zinc oxide/ liter of water (T3). Vitamins and minerals mixture were added in the diet according to the requirements by NRC (1994). By calculation each kilogram of the experimental diets contained $0.13,0.10$ and $0.08 \mathrm{mg}$ inorganic selenium and 26.12, 25.39 and $24.45 \mathrm{mg}$ inorganic zinc for starter, grower and finisher diets respectively.. Water consumption for all treatments was recorded during different periods (Table 3).

At the end of the experiment at 5-weeks of age, four chicks were taken at random from each treatment and sacrificed by cervical dislocation, while blood samples were immediately taken, centrifuged at $3000 \mathrm{rpm}$ for 20 minutes, and then plasma stored at $-20^{\circ} \mathrm{C}$ for later analysis. Blood metabolites were total lipid, cholesterol and triglycerides, total protein, albumin and globulin was calculated by subtract albumin from total protein, plasma urea, creatinine, alanine transaminase (ALT), aspartic transaminase (AST) and triiodothyronine $\left(\mathrm{T}_{3}\right)$. All samples were determined calorimetrically by using commercial kits (By Bio Systems S.A. Costa Brava 30, Barcelona (Spain, Barcelona)). Thyroid hormone (Triiodothronine) was measured by ELISA method using IMMUNOSPEC kits supplied by (Immunospec Corporation, 7018 Owensmounth Ave. Suite 103 Canoga Park, CA 91303, USA). Globulin and albumin / globulin ratio were calculated.

Data were analyzed by one way analysis of variance (Completely Randomized Design), according to the General Linear Models (GLM) procedures of SAS (2002). The difference among means was determined by Duncan's Multiple Range Test (Duncan, 1955). The data were analyzed by the following model:

$$
Y i j=\mu+T_{i}+e_{i j} \text {, }
$$

where: $\mu=$ General mean. $T_{i}=$ random effect of treatment $(i=1,2$ and 3$) . e_{i}=$ a random error. 
Table (1): Composition and calculated analysis of the experimental diets.

\begin{tabular}{lccc}
\hline Item & $\begin{array}{c}\text { Starter diet } \\
(0-10 \text { days })\end{array}$ & $\begin{array}{c}\text { Grower diet } \\
(11-21 \text { days })\end{array}$ & $\begin{array}{c}\text { Finisher } \\
(21-35 \text { days })\end{array}$ \\
\hline Ingredient: & & & \\
Yellow corn & 59.70 & 61.54 & 65.20 \\
Soybean meal 44\% & 27.33 & 27.46 & 25.30 \\
Corn gluten meal 60\% & 7.60 & 4.50 & 3.00 \\
Sunflower oil & 1.50 & 2.80 & 3.30 \\
Calcium carbonate & 1.10 & 1.00 & 0.93 \\
Di-calcium phosphate & 1.80 & 1.69 & 1.47 \\
L-Lysine & 0.35 & 0.25 & 0.18 \\
DL-Methionine & 0.12 & 0.16 & 0.12 \\
Salt & 0.25 & 0.30 & 0.25 \\
Vit.\&Min. Premix* & 0.25 & 0.30 & 0.25 \\
Total & 100.00 & 100.00 & 100 \\
& & & \\
Crude protein \% & 21.81 & 20.10 & 18.53 \\
Calculated composition: & 3037 & 311.8 & 0.76 \\
Calcium \% & 0.91 & 0.84 & 0.38 \\
Available P $\%$ & 0.45 & 0.43 & 1.06 \\
L-Lysine \% & 1.32 & 1.20 & 0.43 \\
DL-Methionine \% & 0.51 & 0.50 & 0.08 \\
Selenium (mg) & 0.13 & 0.10 & 24.45 \\
Zinc (mg) & 26.12 & 25.39 & \\
& & & \\
\hline
\end{tabular}

*Vitamins and minerals premix, each kg contains: Vit A $12000 \mathrm{IU}$, Vit D3 $3000 \mathrm{IU}$, Vit E $12 \mathrm{mg}$, Vit K $1 \mathrm{mg}$, Vit B12 $0.02 \mathrm{mg}$, Vit B1 $1 \mathrm{mg}$, Vit B2 $4 \mathrm{mg}$, Vit B6 $1.5 \mathrm{mg}$, Nicotinic acid $20 \mathrm{mg}$, Folic acid $1 \mathrm{mg}$, Biotin $0.05 \mathrm{mg}$, Choline chloride $160 \mathrm{mg}$, Copper $3 \mathrm{mg}$, Iron $30 \mathrm{mg}$, Manganese $40 \mathrm{mg}$, Zinc $45 \mathrm{mg}$ and Selenium $3 \mathrm{mg}$.

\section{RESULTS AND DISCUSSIONS}

\section{Live body weight and body weight gain:}

The data of live body weight $(\mathrm{g})$ showed that there was nonsignificant difference among treatments in the initial body weight. Broiler that drank water containing sodium selenite (T2) showed the heaviest $(\mathrm{P}<0.01)$ body weight at 21 and 35 days compared to the other treatments. This increase was 22.17 and $14.44 \%$ for treatment T2 at 21 and 35 days of age, respectively compared with (Table 2).

Body weight gain $(\mathrm{g} / \mathrm{bird} / \mathrm{period})$ had the same trend with live body weight. The treatment of broiler that received sodium selenite $(\mathrm{T} 2)$ in the drinking water gained $(\mathrm{P} \leq 0.01)$ more weight than the other treatments during the first three weeks of age and the entire period of the experiments (1-35 days of age) with an increase equal 24.18 and $14.87 \%$, respectively than T1. Although, there was a numerical improvement in body weight gain for the experimental group that drank water containing sodium selenite (T2) during the last two weeks of age (21-35 days of age) but this improvement was non-significant. This improvement was 10.47 and $15.2 \% \%$, respectively than $\mathrm{T} 1$ and $\mathrm{T} 3$. The significant increase of body weight and gain in sodium selenite group (T2) may be due to the ability of sodium selenite to dissolve well in water and its amount was enough to improve the performance of birds. Selenium may affect metabolism and performance because it is essential for the synthesis of active thyroid hormones. Thyroid hormones increased metabolic rate (Hadley, 1984).

Shlig (2009) indicated that the improvement in the live body weight of birds fed selenium could be attributed to some of its biological function such as its role on enzymatic oxidation reduction, nucleic acid metabolism and in promoting the oxidized substances as carotenoids and vitamin A. Selenium may affect metabolism and performance because it is essential for the synthesis of active thyroid hormones. Thyroid hormones increased metabolic rate (Hadley, 1984) and improved the digestibility coefficients of nutrients and nutritive values (Abd El- Galil et al., 2007). 
There were non-significant differences between zinc oxide (T3) and control treatment (T1).

Table (2): Growth performance of Cobb broilers as affected by adding Se and $\mathrm{Zn}$ in drinking water.

\begin{tabular}{|c|c|c|c|c|c|}
\hline \multirow[b]{3}{*}{ Item } & \multicolumn{5}{|c|}{ Treatment } \\
\hline & Control & $\mathrm{Se}$ & $\mathrm{Zn}$ & & \\
\hline & $\mathrm{T} 1$ & $\mathrm{~T} 2$ & $\mathrm{~T} 3$ & $\mathrm{SE}( \pm)$ & Significant \\
\hline \multicolumn{6}{|c|}{ Body weight (g) } \\
\hline Initial & 46.10 & 46.19 & 46.20 & 0.06 & NS \\
\hline At 21 days & $553.80^{\mathrm{b}}$ & $676.60^{\mathrm{a}}$ & $579.40^{\mathrm{b}}$ & 23.44 & $* *$ \\
\hline At 35 days & $1629.00^{\mathrm{b}}$ & $1864.20^{\mathrm{a}}$ & $1610.80^{\mathrm{b}}$ & 39.57 & $* *$ \\
\hline \multicolumn{6}{|c|}{ Body gain (bird/g/period) } \\
\hline $1-21$ days & $507.80^{\mathrm{b}}$ & $630.60^{\mathrm{a}}$ & $533.40^{\mathrm{b}}$ & 23.44 & $* *$ \\
\hline 21-35 days & $1075.00^{\mathrm{ab}}$ & $1187.60^{\mathrm{a}}$ & $1031.00^{\mathrm{b}}$ & 48.41 & NS \\
\hline $1-35$ days & $1582.60^{\mathrm{b}}$ & $1818.00^{\mathrm{a}}$ & $1564.40^{\mathrm{b}}$ & 39.58 & $* *$ \\
\hline \multicolumn{6}{|c|}{ Feed intake (bird/g/period) } \\
\hline 1-21 days & $984.00^{\mathrm{b}}$ & $885.00^{\mathrm{c}}$ & $1012.00^{\mathrm{a}}$ & 7.77 & $* * *$ \\
\hline 21-35 days & $2708.00^{\mathrm{b}}$ & $3050.00^{\mathrm{a}}$ & $2480.00^{c}$ & 53.80 & $* * *$ \\
\hline 1-35 days & $3694.00^{\mathrm{b}}$ & $3936.20^{\mathrm{a}}$ & $3496.00 \mathrm{c}$ & 61.35 & $* * *$ \\
\hline \multicolumn{6}{|c|}{ Feed efficiency ratio (feed/gain) } \\
\hline $1-21$ days & $1.95^{\mathrm{a}}$ & $1.42^{\mathrm{b}}$ & $1.91^{\mathrm{a}}$ & 0.09 & $* * *$ \\
\hline 21-35 days & 2.53 & 2.59 & 2.41 & 0.09 & NS \\
\hline 1-35 days & 2.34 & 2.17 & 2.23 & 0.05 & NS \\
\hline
\end{tabular}

$a, b, c:$ Means within the same row showing different letters are significantly different.

$* *=(P<0.01 \quad * * *=(P<0.001) \quad$ NS $=$ not significant.

\section{Feed intake and feed efficiency ratio:}

The results of feed intake demonstrated that the treatment of broilers received water containing sodium selenite $(\mathrm{T} 2)$ consumed $(\mathrm{P}<0.001)$ more feed than the other groups during the last two weeks $(21-35$ days of age) and the whole experimental period (1-35 days of age). This increase was 12.6 and $6.56 \%$ for the two periods respectively. Furthermore, this treatment $(\mathrm{T} 2)$ consumed less $(\mathrm{P}<0.001)$ feed than the other treatments during the first three weeks of age (1-21 days of age) (Table 2). There was a significant $(\mathrm{P}<0.001)$ reduction in feed intake from 21 to 35 days of age and from 1 to 35 days of age in zinc treatment compared with the other treatments and significant $(\mathrm{P}<0.001)$ increase from 1 to 21 days of age for the same treatment. Regarding feed efficiency ratio, the best ratio was noticed for the treatment $\mathrm{T} 2$ during the periods from 1 to 21 days of age (1.42) and from 1 to 35 days of age (2.17) compared to the other treatments, while there was non-significant $(\mathrm{P}>0.05)$ variation among treatments during the period from 21 to 35 days of age.

Our results are in agreement with Upton et al. (2008) and El-Sheikh et al. (2010) who reported that live body weight of broiler chicks were significantly $(\mathrm{P}<0.05)$ increased in selenium (Sel-Plex $\left.{ }^{\mathrm{TM}}\right)$ treatment compared to the control treatment. Therefore, the body weight and feed efficiency were better in the treatment supplemented with excess of selenium and vitamin $\mathrm{E}$ in the diet than the control treatment (Bobade et al., 2009). Many studies have reported beneficial influences of selenium supplementation on feed intake, body weight, weight gain and the prevention of selenium deficiency symptoms and mortality in poultry (Christine et al., 2002, Choct et al., 2004 and Ibrahim et al., 2011). On the contrary, Dalia et al. (2017) demonstrated that supplementation of inorganic selenium did not change body weight, weight gain, feed intake and feed efficiency ratio. Moreover, Chen et al. (2013) investigated the effect of different levels of organic selenium $(0.3,0.5,1$ and $2 \mathrm{mg} / \mathrm{kg} \mathrm{diet})$ on growth performance and mortality rate and found that there were non-significant differences among treatments until $2 \mathrm{mg} / \mathrm{kg}$ diet. Likewise, selenium supplementation until $0.3 \mathrm{mg} / \mathrm{kg}$ diet did not influence the growth performance of broilers (Yoon et al., 2007). Using different combination levels of selenium and vitamin $\mathrm{E}$ in broiler chick's diet didn't result in any significant differences in feed intake and feed efficiency ratio among all treatments and control (Tayeb and Qader, 2012). 
Regarding zinc oxide, the current results agree with those of Kim and Patterson (2004) who investigated that zinc oxide treatments $(0.5,1$ and $1.5 \mathrm{gm})$ had no negative effects on growth performance and there were no significant differences in weight gain compared to the control treatment. Therefore, Collins and Moran (1999) reported that body weight and feed efficiency were not influenced by feeding excessive levels of supplemented $\mathrm{Zn}$. The significant reduction in feed intake of chicks fed soluble form of $\mathrm{Zn}$ at concentrations above $600 \mathrm{mg} / \mathrm{kg}$ in diets has been reported by Henry et al. (1987) and Sandoval et al. (1998). On the contrary, Dönmez et al. (2001) showed that body weight gain was significantly lower and feed efficiency was significantly higher in chicks supplemented with excess amounts of zinc (500 or $1000 \mathrm{mg} \mathrm{Zn}$ as $\mathrm{ZnSO}_{4} / \mathrm{L}$ of drinking water) compared to chicks supplemented with control treatment or $125 \mathrm{mg} \mathrm{Zn} / \mathrm{L}$ of drinking water at the end of the experiment. Likewise, Sarvari et al. (2015) represented that birds fed the diets containing $0.01 \% \mathrm{ZnO}$ presented higher weight gain than those fed the diets with no $\mathrm{ZnO}(\mathrm{P}<0.01)$.. In our study, there was no difference in body weight gain and feed efficiency ratio between birds received 1000 $\mathrm{mg} \mathrm{ZnO} / \mathrm{L}$ of drinking water and control group. These differences among researches could be due to differences in period of time for exposure to $\mathrm{Zn}$ and $\mathrm{Zn}$ source.

\section{Water consumption:}

The results of water consumption are represented in Table (3). Treating birds with sodium selenite led to an increase in water consumption. This increase was 50.49, 15.63 and $29.28 \%$ during the first three weeks (1-21 days), the last two weeks (21-35 days) and whole period (1-35 days) of experiment respectively. About zinc oxide treatment (T3), the birds consumed more water than the control treatment during the last two weeks of age (21-35 days) and all period of experiment (1-35 days). This increase was 20.31 and $11.41 \%$ respectively. This result may be due to addition of selenium and zinc in broiler drinking water improved water taste compared to control treatment. Broiler has a keen sense of taste and prefers water that is slightly acidic (Kare, 1970).

Table (3): Water consumption of Cobb broilers as affected by adding Se and $\mathrm{Zn}$ in drinking water.

\begin{tabular}{llll}
\hline & \multicolumn{3}{c}{ Treatment } \\
\cline { 2 - 4 } Item & Control & Se & Zn \\
\cline { 2 - 4 } Water consumption $(\mathrm{L})$ & $\mathrm{T} 1$ & $\mathrm{~T} 2$ & $\mathrm{~T} 3$ \\
1 1-21 days & 206 & 310 & 179 \\
$21-35$ days & 320 & 370 & 385 \\
$1-35$ days & 526 & 680 & 586 \\
\hline
\end{tabular}

\section{Blood biochemical profiles:}

Data of plasma total protein, albumin, globulin, albumin/globulin ratio, total lipid, cholesterol, triglycerides, $\mathrm{T}_{3}$, urea, creatinine, ALT and AST is shown in Table (4). The current results demonstrated that there were non-significant $(\mathrm{P}>0.05)$ differences among treatments for plasma total protein, albumin, globulin and their ratio (A/G ratio). These results are in agreement with those obtained by Sarvari et al. (2015) who reported that the effects of dietary zinc oxide on total protein and albumen were non-significant. Likewise, Barman et al. (2009) did not report any significant effect of different dietary zinc supplementation level on serum protein. On contrary, Bahakaim et al. (2014) reported that those of organic zinc supplementation significantly increased plasma total protein, albumin, and globulin and improved A/G ratio in laying hens compared to the control treatment. In the same way, Refaie (2009) found that the group of chicks fed diets supplemented with organic zinc (Biozink) at either $120 \mathrm{mg}, 80 \mathrm{mg}$ or $40 \mathrm{mg} \mathrm{Zn} / \mathrm{kg}$ diet recorded the highest total protein, globulin and significantly differed compared to all other groups which fed the control or 40, 80, and $120 \mathrm{mg}$ supplemental $\mathrm{Zn}$ as zinc oxide.

Regarding selenium addition, the results agree with Yang et al. (2012) and Dalia et al. (2017) who demonstrated that supplementation of inorganic or bacterial organic selenium did not affect total protein, albumin, globulin, albumin/globulin ratio in broiler chicks. Contrary to our findings, Mohapatra et al. (2014) stated that supplementation of $0.3 \mathrm{ppm}$ nano Se in layer chicks up to 8 weeks significantly increased total protein and serum globulin levels and also significantly lowered albumin/globulin ratio compared to control treatment. 


\section{Salem et al.}

Table (4): Blood biochemical profiles of Cobb broilers as affected by adding Se and Zn in drinking water.

\begin{tabular}{|c|c|c|c|c|c|}
\hline \multirow[b]{3}{*}{ Item } & \multicolumn{5}{|c|}{ Treatment } \\
\hline & Control & $\mathrm{Se}$ & $\mathrm{Zn}$ & & \\
\hline & T1 & $\mathrm{T} 2$ & T3 & $\mathrm{SE}( \pm)$ & Significant \\
\hline Total protein $(\mathrm{mg} / \mathrm{dl})$ & 4.1 & 3.85 & 3.64 & 0.39 & NS \\
\hline Albumin (mg/dl) & 2.48 & 2.52 & 2.48 & 0.08 & NS \\
\hline Globulin (mg/dl) & 1.62 & 1.33 & 1.17 & 0.33 & NS \\
\hline $\mathrm{A} / \mathrm{G}$ ratio & 1.83 & 2.27 & 2.2 & 0.40 & NS \\
\hline Total lipid (mg/dl) & 413.30 & 424.55 & 374.30 & 18.83 & NS \\
\hline Colesterol (mg/dl) & 141.4 & 136.15 & 140.65 & 8.11 & NS \\
\hline Triglycerides (mg/dl) & 174.3 & 211.55 & 167.55 & 36.83 & NS \\
\hline T3 (nmol/l) & $3.26^{\mathrm{c}}$ & $3.62^{\mathrm{ab}}$ & $3.80^{\mathrm{a}}$ & 0.11 & $*$ \\
\hline Urea $(\mathrm{g} / \mathrm{dl})$ & 12.25 & 12.75 & 12.5 & 1.53 & NS \\
\hline Createnine (mg/dl) & 1.58 & 1.80 & 1.72 & 0.08 & NS \\
\hline $\operatorname{ALT}(\mathrm{g} / \mathrm{dl})$ & 166.45 & 187.2 & 173.2 & 20.40 & NS \\
\hline $\operatorname{AST}(\mathrm{g} / \mathrm{dl})$ & 21.28 & 20.65 & 16.93 & 6.89 & NS \\
\hline
\end{tabular}

a,b,c: Means within the same row showing different letters are significantly different.

$*=(P<0.05) \quad$ ** $=(P<0.01) \quad$ NS $=$ not significant.

There were not significant differences among treatments for plasma total lipid, cholesterol and triglycerides. There was a numerical decrease in plasma cholesterol for selenium (T2) treatment compared to the control treatment and zinc treatment (T3). About plasma total lipid and triglycerides, there was a numerical decrease for zinc oxide treatment (T3). These results are in agreement with, Sarvari et al. (2015) who reported that the effects of dietary zinc oxide on plasma cholesterol and triglycerides were nonsignificant. On contrary, Ahmadi et al. (2013) represented that zinc oxide nanoparticles had resulted in low triglycerides and total cholesterol. Likewise, Kucuk et al. (2003) concluded that supplementing Zn to broiler diets decreased blood cholesterol.

Selenium results disagree with Fawzy et al. (2016) who showed that sodium selenite caused a decrease in serum cholesterol and triglycerides of broiler.

Our results of plasma $\mathrm{T}_{3}$, urea, creatinine, ALT and AST showed a significant $(\mathrm{P}<0.05)$ increase in triiodothyronine $\left(\mathrm{T}_{3}\right)(\mathrm{P}<0.01)$ for selenium and zinc treatments $(\mathrm{T} 2$ and $\mathrm{T} 3$ respectively) compared to the control treatment while, there were non-significant differences among the experimental treatments for plasma urea, creatinine, alanine transaminase (ALT) and aspartic transaminase (AST).

The high level of plasma thyroid hormone $\left(\mathrm{T}_{3}\right)$ for selenium and zinc treatments (T2 and $\mathrm{T} 3$, respectively) compared to the control treatment may be due to selenium is required for the expression of the selenoenzymes type I (ID-I) and type II (ID-II) iodothyronine deiodinase, which are necessary for the generation of the active hormone 3,3',5-tri-iodiothyronine (T3). Type I iodothyronine deiodinase (ID-I) catalyzes the deiodination of thyroxin (T4) to 3, 3'5-tri-iodothyronine (T3). Therefore, there is a close relationship between zinc concentration and thyroid hormone level in body (Fujimoto et al., 1986). The later authors added that triiodothyronine $\left(\mathrm{T}_{3}\right)$ level decreased significantly in zinc-deficient rats. The enzymes which play an important role on the deiodenation of thyroxine $\left(\mathrm{T}_{4}\right)$ to Triiodothyronine $\left(\mathrm{T}_{3}\right)$ need selenium and zinc to function (Nishiyama et al., 1994).

The results of triiodothyronine $\left(\mathrm{T}_{3}\right)$ agree with Srimongkol (2003), Upton et al. (2008) and El-Sheikh et al. (2010) who indicated that triiodothyronine $\left(\mathrm{T}_{3}\right)$ hormone was significantly $(\mathrm{P}<0.05)$ increased in broiler fed selenium supplementation compared to those fed a basal diet. On contrary, Pappas et al. (2017) concluded that supplementation with selenium alone or in combination with vitamin $\mathrm{E}$ in broiler diets above their requirements did not affect thyroid hormone metabolism. Therefore, Dönmez et al. (2001) reported that serum triiodothyronine level was significantly reduced with high zinc levels (500 and $1000 \mathrm{mg} \mathrm{Zn}$ as $\mathrm{ZnSO}_{4} /$ $\mathrm{L}$ of drinking water) of zinc intake. The difference between our findings and other experiments may be due to the type of used selenium and zinc and their characteristics, the time of the experiment and age of broiler. 
Plasma urea and creatinine are commonly used as indicator of kidney function (Perrone et al., 1992) while ALT and AST are biochemical markers of liver function and health (Nyblom et al., 2004 and Che et al., 2011). An elevation in the levels of these parameters is considered to be a sensitive indication of liver injury while the reduction means increasing protection for the broiler health.

Regarding selenium supplementation, there were non-significant differences between selenium treatment and control for urea, creatinine, ALT and AST. These results agree with the results of Gružauskas et al. (2013), Okunlola et al. (2015) and Dalia et al. (2017) who indicated that there were no differences in urea and creatinine in poultry supplemented with organic or inorganic selenium. At the opposite way, Peric et al. (2009), Biswas et al. (2011) and Dalia et al. (2017) showed that Se supplementation as inorganic or organic forms significantly decreased $(\mathrm{P}<0.05)$ the activities of AST, ALT enzymes and creatinine level in birds fed selenium compared to basal diet.

\section{Carcass traits:}

The effect of the experimental treatments on the carcass weight (g) and relative value of carcass, empty carcass, head, legs, liver, heart, gizzard, bursa, spleen, pancreas, gastrointestinal tract weight, intestine weight and intestine long as percent (\%) of live body weight is shown in Table (5). All treatments had no significant effect on carcass traits. These results are in agreement with those of Payne and Southern (2005) who reported that carcass traits were not affected $(\mathrm{P}>0.05)$ by selenium source or level of supplementation. Likewise, Tayeb and Qader (2012) showed that selenium and vitamin E had no significant effect on carcass weight, carcass parts and dressing percentage at 42 and 49 days of age.

Table (5): Carcass traits of Cobb broilers as affected by adding Se and $\mathrm{Zn}$ in drinking water.

\begin{tabular}{|c|c|c|c|c|c|}
\hline \multirow[b]{3}{*}{ Item } & \multicolumn{4}{|c|}{ Treatment } & \multirow[b]{3}{*}{ Significant } \\
\hline & Control & $\mathrm{Se}$ & $\mathrm{Zn}$ & & \\
\hline & $\mathrm{T} 1$ & $\mathrm{~T} 2$ & T3 & $\mathrm{SE}( \pm)$ & \\
\hline Final live weight $(\mathrm{g})$ & 1616.7 & 2023.3 & 1811.7 & 109.10 & NS \\
\hline Carcass weight (\%) & 96.89 & 95.95 & 97.72 & 0.76 & NS \\
\hline Empty carcass weight (\%) & 87.15 & 88.75 & 89.59 & 1.18 & NS \\
\hline Head weight (\%) & 2.26 & 2.15 & 2.30 & 0.15 & NS \\
\hline Leg weight $(\%)$ & 4.43 & 3.41 & 4.12 & 0.69 & NS \\
\hline Liver weight $(\%)$ & 2.53 & 3.21 & 2.58 & 0.26 & NS \\
\hline Heart weight $(\%)$ & 0.67 & 0.65 & 0.59 & 0.06 & NS \\
\hline Gizzard weight (\%) & 3.41 & 3.11 & 2.91 & 0.29 & NS \\
\hline Bursa weight (\%) & 0.12 & 0.14 & 0.10 & 0.03 & NS \\
\hline Spleen weight $(\%)$ & 0.19 & 0.17 & 0.11 & 0.04 & NS \\
\hline Pancreas weight $(\%)$ & 0.28 & 0.32 & 0.31 & 0.04 & NS \\
\hline Gastrointestinal tract weight $(\%)$ & 10.92 & 10.98 & 10.23 & 0.69 & NS \\
\hline Intestinal weight (\%) & 6.28 & 7.91 & 2.51 & 1.52 & NS \\
\hline Intestinal long $(\%)$ & 11.50 & 11.06 & 10.45 & 0.63 & NS \\
\hline
\end{tabular}

Ns = not significant.

As well, our carcass traits findings are consistent with Liu et al. (2011), Sarvari et al. (2015) and Zakaria et al. (2017) who showed that carcass traits were not affected by $\mathrm{Zn}$ source or the interaction between $\mathrm{Zn}$ source and supplemental Zn level or the high Zn concentration. On contrast, Jahanian et al. (2008) reported that increasing $\mathrm{Zn}$ supplemental levels from 40 to $80 \mathrm{mg} / \mathrm{kg}$ from both inorganic and organic zinc sources increased liver weight percentage.

The final results of each experiment are affected by many factors such as the source and the concentration of minerals, the administration methods for broiler, the environmental conditions of each experiment and age of broiler. 


\section{Salem et al.}

\section{Mortality rate:}

The results of the mortality rate were represented in Figure (1). The data of the mortality rate during the whole period of the experiment showed that zinc treatment (T3) recorded the lowest percent $(3.85 \%)$ of mortality followed by selenium treatment (T2) $(6.25 \%)$, while the control treatment recorded the highest percent of mortality rate $(10.81 \%)$. These findings may be due to zinc and selenium act as antioxidant and immuno-stimulating substances which increase the ability of the immune system to resist diseases by improving immune response. Calnago et al. (1984) and Madron and Vrzgulova (1988) reported that selenium supplementation enhanced the immune system in chicken and increased the natural resistant of broiler by increasing their response to antigenic stimuli. Our data are on contrary with Cantor et al. (1975 a,b), Edens et al. (2001) and Payne and Southern (2005) who reported that mortality was not affected by selenium source or level.

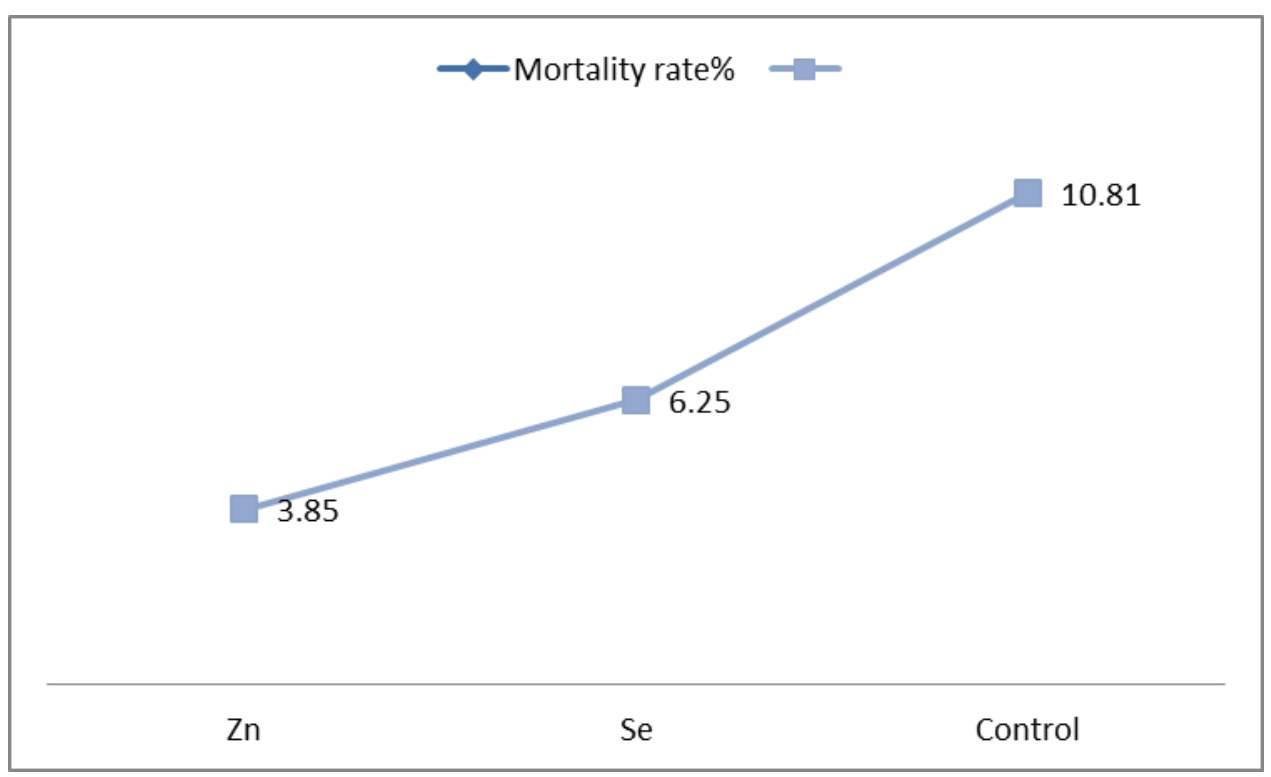

Figure (1): Mortality rate (\%) of Cobb broilers as affected by adding Se and $\mathrm{Zn}$ in drinking water.

\section{CONCLUSION}

The results concluded that supplementation of sodium selenite $(0.8 \mathrm{mg} / \mathrm{liter})$ on broiler drinking water improved growth performance and zinc oxide $(1000 \mathrm{mg} / \mathrm{liter})$ did not have adverse effects on growth rate and the functions of blood.

\section{REFERENCES}

Abd El-Galil, H.A. Mahmoud and K.M. Abu el-Soud (2007). Response of growing Japanese quail to different levels of protein with or without vitamin E and selenium supplementation. J. Agric Sci. Mansoura Univ., 32(9): 7157-7175.

Ahmadi, F., Y. Ebrahimnezhad, N.M. Sis and J.G. Ghalehkandi (2013). The effects of zinc oxide nanoparticles on performance, digestive organs and serum lipid concentrations in broiler chickens during starter period. Int. J. bio. Sci., 3:23-29.

Bahakaim, A.S.A., Hamat. A. Abdel Magied, Sahar, M.H. Osman, Amal S. Omar, Abdel Malak, N.Y. and Nehad A. Ramadan (2014). Effect of using different levels and sources of zinc in layer's diets on egg zinc enrichment. Egypt. poult. Sci. J., Vol. (34) (I): 39-56. 
Barman, C., J. Goswami and B.C. Sameh (2009). Effect of zinc supplementation on feed consumption and growth performance of broiler chicks. Int. Vet. J., 86(11):1154-1155.

Biswas, A, M. Ahmed, V. Bharti and S. Singh (2011). Effect of antioxidants on physio biochemical and hematological parameters in broiler chicken at high altitude. Asian Aust. J Anim. Sci., 24 (2): 246-249.

Bobade, S.P., A.N. Sarage, D.H. Rekhate, A.P. Dhok and S.V. Joge (2009). Efficacy of vitamin E and selenium on growth performance of broilers. Vet. World, Vol. 2(1): 20-21.

Calnago, G. L.; L. S. Jensen and P. L. Long (1984). Effect of selenium and vitamin E on the development of immunity to coccidiosis in chickens. Poult. Sci., 63: 1136-1143.

Cantor, A.H., M.L. Scott and T. Noguchi (1975a). Biological availability of selenium in feedstuffs and selenium compounds for prevention of exudative diathesis in chicks. J. Nutr., 105: 96-105.

Cantor, A. H., M. L. Scott and T. Noguchi (1975b). Efficacy of selenium in selenium compounds and feedstuffs for prevention of pancreatic fibrosis in chicks. J. Nutr., 105:106-111.

Che, Z.Q., Y.L. Liu, H.R. Wang, H.L. Zhu, Y.Q. Hou and B.Y. Ding (2011). The protective effects of different mycotoxin adsorbents against blood and liver pathological changes induced by mold contaminated feed in broilers. Asian-Aust. J. Anim. Sci., 24: 250-257.

Chen. G., J. Wu and C. Li (2013). The effect of different selenium levels on production performance and biochemical parameters of broilers. Ital. J. Anim. Sci., vol.12:e79.

Choct, M., A.J. Naylor and N. Reinke (2004). Selenium supplementation affects broiler growth performance, meat yield and feather coverage. Bri. Poult. Sci., 45: 677-683.

Christine A. Zuberbuhle, Ruth E. Messikommer and W. Caspar (2002). Choice feeding of seleniumdeficient laying hens affects diet selection, selenium intake and body weight. J. Nutr., 132:3411-3417.

Collins, N.E. and Jr. E.T. Moran (1999). Influences of supplemental manganese and zinc on live performance and carcass quality of diverse broiler strains. J. Appl. Poult. Res., 8:228-235.

Combs, G.F. and S.B. Combs (1986). The role of selenium in nutrition. Academic Press. New York, NY, USA.

Dalia, A.M., T.C. Loh, A.Q. Sazili, M.F. Jahromi and A.A. Samsudin (2017). The effect of dietary bacterial organic selenium on growth performance, antioxidant capacity and selenoproteins gene expression in broiler chickens. BMC Vet. Res., 13: 254-265.

Dönmez, H.H., M.A. Karsli, I. Meral, N. Dönmez and N. Şimşek (2001) Effects of increasing zinc supplementation in drinking water on growth and thyroid gland function and histology in broiler chicks. Dtsch. Tierärztl. Wschr. 109: 438-442.

Duncan, D.B. (1955). Multiple range and multiple F-test. Biometrics 11:1-42.

Edens, F.W., C.R. Parkhurst, G.B. Havenstein and A.E. Sefton (2001). Housing and selenium influences on feathering on broilers. J. Appl. Poult. Res., 10:128-134.

El-Sheikh, A.M.H., E.A. Abdalla and M. M. Hanafy (2010). The effect of organic selenium supplementation on productive and physiological performance in a local strain of chicken. Egypt. Poult. Sci. J. Vol (30) (II): (517-533).

Fawzy, M.M., H.A. El-Sadawi, M.A. El-Dien and W.A.M. Mohamed (2016). Hematological and biochemical performance of poultry following zinc oxide and sodium selenite supplementation as food additives. Annals of Clinical Patho., 4(4): 1076.

Fujimoto, Y.I., A. Higashi, I. Matsuda , E.E. Kashiwabara, I.Nakashima (1986). Conversion of thyroxine into triiodothyronine in zinc deficient rat liver. J. Pediatr. Gastroenterol. Nutr., 5: 799-805.

Gružauskas, R., T. Barštys, A. Racevičiūtė-Stupelienė, V. Kliševičiūtė, V. Buckiūnienè and S. Bliznikas (2013). The effect of sodium selenite, selenium methionine and vitamin $\mathrm{E}$ on productivity, digestive processes and physiologic condition of broiler chickens. Veterinarija ir Zootechnika, 65(87):22-9. 


\section{Salem et al.}

Hadley, M. E. (1984). Pancreatic hormones and metabolic regulation. Thyroid hormones and hormones of males reproductive physiology, In: Endocrinology, pp. 235-263, 292-317, 402-420, Prentica-Hall, Inc., Englewood cliffs, N.J.

Henry, P.R., C.B. Ammerman and R.D. Miles (1987). Effects of dietary zinc on tissue mineral concentrations a measure of zinc bioavailability in chicks. Nutr. Report Int., 35:15-23.

Huang Y. L., L. Lu, X. G. Luo, and B. Liu (2007). An Optimal Dietary Zinc Level of Broiler Chicks Fed a Corn-Soybean Meal Diet. Poult. Sci., 86:2582-2589.

Ibrahim, M.T., B.H. Eljack and I.M.T. Fadlalla (2011). Selenium supplementation of broiler diets. Anim. Sci. J. 2(1):12-17.

Jahanian, R., H.N. Moghaddam and A.Rezaei (2008). Improved broiler chick performance by dietary supplementation of organic zinc sources. Asian-Aust. J. Anim. Sci., Vol. 21, No. 9: 1348 - 1354.

Kare, M.R. (1970). The chemical senses of birds. bird control seminars proceedings. Available at: http://digitalcommons.unl.edu/cgi/viewcontent.cgi?article=1183\&context=icwdmbirdcontrol. Accessed $10 / 4 / 12$.

Kim, W. K. and P. H. Patterson (2004). Effects of dietary zinc supplementation on broiler performance and nitrogen loss from manure. Poul. Sci., 83:34-38.

Kucuk, O., N.Sahin and K. Sahin (2003). Supplemental zinc and vitamin A can alleviate negative effects of heat stress in broiler chickens. Boil. Trace Elem. Res., 94(3):225 - 235.

Liu, Z.H., L.Lu, S.F. Li, L.Y. Zhang, L. Xi, K.Y. Zhang and X.G. Luo (2011). Effects of supplemental zinc source and level on growth performance, carcass traits and meat quality of broilers. Poul. Sci., 90: 17821790.

Macpherson, A. (1994). Selenium, vitamin E and biological oxidation. In: Cole DJ, Garnsworthy PJ, editors. Recent advances in animal nutrition. Oxford: Butter worth and Heinemann, p. 3-30.

Madron, P. and N.Vrzgulova (1988). Vitamin E and selenium increase the natural resistance of farm animals. Veterinarstvi. 38: 369-371.

Meremikwu, V.N., O. Akpet A. Essien and E.E. Orok (2015). Effects of folic acid supplementation on the performance of broiler chicken, J. Agri., Forestry and the Social Sci., Vol. 13, No 1.

Mohapatra P, R. Swain, S. Mishra, T. Behera, P. Swain and S. Mishra (2014). Effects of dietary nanoselenium on tissue selenium deposition, antioxidant status and immune functions in layer chicks. Int J Pharmacol., 10 (3): 160-167.

Nishiyama, S., Y. Futagoish, M. Matsukara, T. Nakamura, A. Higashi, M. Shinohara and I.Matsuda (1994). Zinc supplementation alters thyroid hormone metabolism in disabled patients with zinc deficiency. J. American College Nutr., 13:62-67.

NRC (1994). National Research Council. Nutrient Requirements of Poultry. 9th rev. ed. National Academy Press, Washington, DC, USA.

Nyblom, H., U. Berggren, J. Balldin and R.Olsson (2004). High AST/ALT ratio may indicate advanced alcoholic liver disease rather than heavy drinking. Alcohol, 39: 336-339.

Okunlola, D.O., T.O. Akande, H.A. Nuga (2015). Haematological and serum characteristics of broiler birds fed diets supplemented with varying levels of selenium powder journal of biology. Agriculture and Healthcare, 5(1):107-10.

Oteiza, P.L., K.L. Olin, C.G. Fraga and C.L. Keen (1996). Oxidant defense systems in testes from Zn deficient rats. Proc. Sac. Exp. Biol. Med, 213: 85-91.

Pappas, A.C., P.M. Kotsampast, K. Kalamaras, K. Fegeros, G. Zervas, D. Kalogiannis and S.E. Chadio (2017). Effects of concomitant selenium and vitamin E administration on thyroid hormone metabolism in broilers. J. Hellenic Vet. Med. Society, Vol. 68, No 3: 355-362.

Payne, R.L. and L.L. Southern (2005). Comparison of inorganic and organic selenium sources for broilers. Poult. Sci., 84:898-902. 
Periæ L, N.Miloševiæ , D. Žikiæ, Z. Kanaèki, N. Džiniæ and L. Nollet (2009). Effect of selenium sources on performance and meat characteristics of broiler chickens. j. Appl. Poult. Res., 18 (3): 403-409.

Perrone, R.D., N.E. Madias and A.S. Levey (1992). Serum creatinine as an index of renal function: New insights into old concepts. Clin. Chem., 38: 1933-1953.

Refaie, A.M. (2009). Performance and immunoocompetence of broilers as affected by zinc protein and phytase supplementation during summer season. Dept. of Anim. Nutr., Fac. of Agri. Cairo Univ.

Ross Management Guide. Broiler management guide 308. (2009). Available from: $\underline{w w w . a v i a g e n . c o m}$.

Rotruck, J.T., A.L. Pope, H.E. Ganther, A.B. Swanson, D.G. Hafeman and W.G. Hoekstra (1973). Selenium biochemical role as a component of glutathione peroxidase. Science, 179: 588-590.

Ryu, K.S., Kevin D. Roberson and Gene M. Pesti (1995). The folic acid requirements of starting broiler chicks fed diets based on practical ingredient. 1. Interrelationships with dietary choline. Poult. Sci., 74: 1447-1455.

Sandoval, M., P. R. Henry, X. G. Luo, R. C. Littell, R. D. Miles and C. B. Ammerman (1998). Performance and tissue zinc and metallothionein accumulation in chicks fed a high dietary level of zinc. Poult. Sci., $77: 1354-1363$

Sarvari, B.G., A.H. Seyedi, H.A. Shahryar, M. Sarikhan and S.Z. Ghavidel (2015). Effects of dietary zinc oxide and a blend of organic acids on broiler live performance, carcass traits and serum parameters. Brazil. J.Poult. Sci. Special issue, 39:46.

SAS. (2002). Statistical analysis systems user's guide: Version 8.0. Cary: SAS Institute.

Schlussel, Y.R. (2006). Mineral absorption and deficiency. Ph.D. Research Scientist, Dept. of Nutr. Sci. Rutgers Univ., New Brunswick, NJ.

Shlig, A.A. (2009). Effect of vitamin E and selenium supplement in reducing aflatoxicosis on performance and blood parameters in broiler chicks. Iraqi J. Vet. Sci., 23:97-103.

Srimongkol, C. (2003). Effects of selenium supplementation on growth performance, thyroid hormone (T3) Levels, antioxidant enzyme and disaccharidase activities in broiler chicks. Thesis M.Sc. Chulalongkorn Univ.

Tayeb, I.T and G.K. Qader (2012). Effect of feed supplementation of selenium and vitamin E on production performance and some hematological parameters of broiler. KSÜ Doğa Bil. Derg., 15 (3), 46-56.

Upton, J. R., F. W. Edens and P. R. Ferket (2008). Selenium yeast effect on broiler performance. Int. J. Poult. Sci., 7: 798-80.

Yang Y., F. Meng, P.Wang, Y.Jiang, Y Q. In and J. Chang (2012). Effect of organic and inorganic selenium supplementation on growth performance, meat quality and antioxidant property of broilers. Afr $\mathrm{J}$ Biotechnol., 11 (12): 3031-3036.

Yoon, I., T.M. Werner and J.M. Butler (2007). Effect of source and concentration of selenium on growth performance and selenium retention in broiler chickens. Poult. Sci., 86:727-730.

Zakaria, H.A., M.Jalal, H.H. AL-Titi and A. Souad (2017). Effect of sources and levels of dietary zinc on the performance, carcass traits and blood parameters of broilers. Brazil. J. Poult. Sci., Vol. 19 (3): 519-526. 


\title{
Salem et al.
}

\section{الاور المؤثر للسيلينيوم و الزنك على اداء بداري التسمين}

\author{
فايزة محمد منصور سالم ، امال حمح حسن2 ، عبد الدايم عبد العزيز عبد الدايم ${ }^{2}$ و خالد عبد الجليل1 \\ 1 قسم تغذية الحيوان و الدواجن-مركز بحوث الصحراء - القاهرة - مصر. \\ 2قسم فسيولوجيا الحيوان و اللواجن-مركز بحوث الصحراء ـ القاهرة -مصر.
}

\begin{abstract}
تم استخدام عدد تسعين كتكوت Cobb 500 عمر يوم غير مجنس في هذة التجربة. يهدف هذا العمل الى زيادة المتاح و التاثير الايجابى

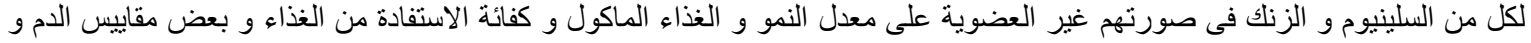

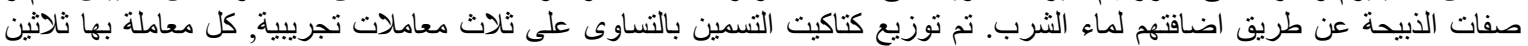

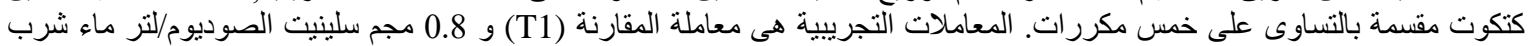

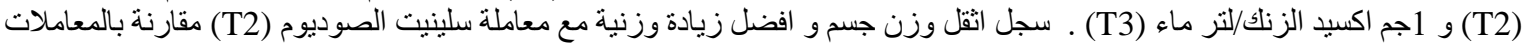

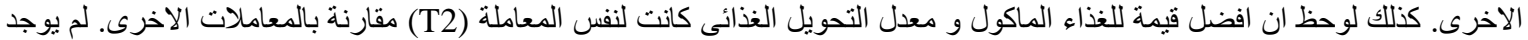

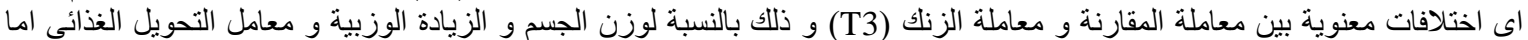

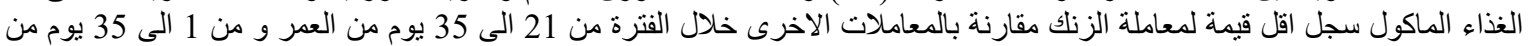

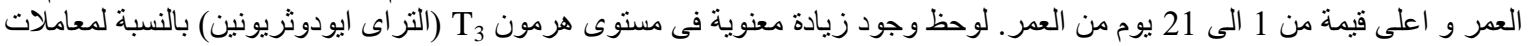

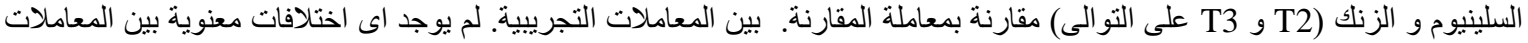

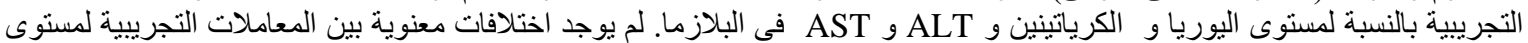

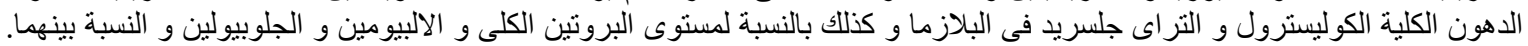

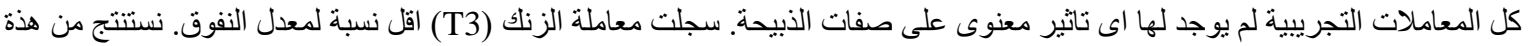

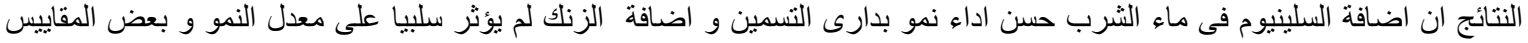

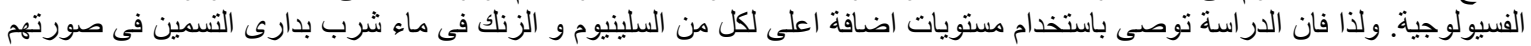

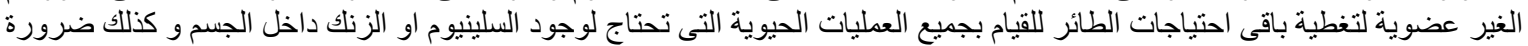
اجر اء بحوث مستقبلية لتغطية كل العو امل المؤثرة و العو امل التطبيقية.
\end{abstract}

